\title{
Application of psychological and pedagogical resources in foreign language teaching: a communicative perspective
}

\author{
T. M. Ahibalova, O. V. Alpatova
}

Kharkiv National Air Force University named after Ivan Kozhedub, V. N. Karazin Kharkiv National University

Corresponding author. E-mail: tanika.fem@gmail.com, alpatova.olena@gmail.com

Paper received 29.01.18; Revised 03.02.18; Accepted for publication 05.02.18.

https://doi.org/10.31174/SEND-Ph2018-152VI45-01

\begin{abstract}
The article analyzes the methods and resources of FLT from a psychological, pedagogical and communicative points of view. The prominent approaches in foreign language teaching are targeted at communicative competence of the participants of the educational process, since it covers a number of factors important for successful mastery in language material. Memorization as a basis for learning is directly related to mental processes that allow a transition from communicative experience to skills as a higher motivational and reflective level. Investigated psychological and pedagogical resources are outlined in terms of their aims and results, and examples of methods and means of their realization in the educational process are given.
\end{abstract}

Keywords: language competence, language world view, psychological resource, teaching method, motivation.

Introduction. A high level of foreign language mastery is a distinctive sign of a highly educated person. This fact proves true people's intentions to study languages as international means of communication, in particular the English language and languages of countries, where they work or study. Ukrainian education is developing its international relations with different spaces of the world culture, and in recent years the number of Ukrainian and foreign students, who apply for higher education and develop competitive skills in foreign language proficiency within our country, has sharply increased. Participants gane their knowledge resource in accordance with a current FL Curriculum, which provides the foreign language education, whether English for local students and outcomers, or Ukrainian for foreigners, as an integral deposit into successful career. The main mission of a teacher, in turn, is to use methods and forms of education that will enable students to master the language as quickly and easily as possible, and to consolidate the gained knowledge for a long time, as much as effectively use them in communication.

Brief review on scientific sources and publications. Numerous works of Ukrainian and foreign researchers prove impossibility to find a single universal model of education for all participants` requirements. This motivates the need for a thorough analysis of the capabilities of a specific group or person who comprehend the language (S. Bilobram, S. Yefendiyeva, L. Levko, S. Muntyan). In particular, J. Hayes emphasizes the need to take into account communicative competences, which depend on the available knowledge of the language and the ability to situatively apply them. An obstacle to the use of knowledge already acquired is a series of psychological or communicative barriers, which complexity, definition and classification are investigated by G. Andreyeva, T. Bazarov, K. Rogers, V. Stolin, M. Forverg, I. Shcherban). When studying the effectiveness of learning foreign language, everyone agrees that the process of involving into real communication is highly productive $(\mathrm{N}$. Bilan, A. Gavrilyuk, O. Kuznetsova, E. Passov).

The purpose of the presented paper, therefore, is to clarify effective psychological and pedagogical preconditions, means and methods of teaching that help develop students`spoken skills, ways to use them during classes and for self-training.
Materials and methods. Acquiring a language is an ongoing process because the language itself is constantly changing, therefore current researchers try to find novel and innovative models on a background of J. Harmer's idea that the assimilation of foreign languages should be directed not to the level of language proficiency as final result, but on the system of approaches that involves the process of acquiring communicative skills. In its turn, it refers to the use of communicative skills and unceasing use of given in language units information under the guidance of a teacher. In accordance with this, N. Khom$\underline{\text { sky introduces the notion of "competence", which has }}$ been transformed in further investigation attempts of scholars into a "communicative competence" and understood as an ability to communicate through the use of a particular language and does not require a prior definition of the level of language proficiency [1, p. 107].

The mentioned principle of teaching is also rational from a psychological point of view, since a language competence passes to the intuitive level, and the foreign language itself becomes an additional motive for the intellectual and professional development of a specialist. This is emphasized by S. Tsymbal, who indicates a number of psychological resources to be involved into FLT:

1) communicative and role, interactive, socialization direction;

2) language orientation;

3) gnostic, cognitive direction;

4) personality-oriented approach;

5) regulatory and willing orientation;

6) creative direction;

7) activity orientation;

8) motivation orientation [4].

Results consideration. In order to prove the necessity to take the given aspects of teaching into consideration we analyze the possibility of these resources implementation all through classes or during students' self-training.

Communicative and role orientation is to involve students in communication, social perception, the use of participants' role potential, and empathy, used in the process of learning a foreign language. It plays a leading role in the process of language learning and comprehending, since it is actually an implementation of the very purpose of education - the acquisition of skills and communication experience. Through oral interpersonal exchange students become successful in the use of acquired 
knowledge and perceive new language input. There is no doubts, it is considered to be an effective method at this stage for dialogue, which will promote the mechanical absorption of certain structures. Close to this is the method of questions and answers, which refers to a certain list of specially selected or developed questions and answer options. This method contributes to the rapid tempo of learning, since there is no need for the previous translation of the training material, and the mechanical use of it, and the transfer of the received information to the intuitive level, that is, it develops skills to think in a foreign language. These methods are complementary ones. The socialization orientation should be used during students self-training, as during the dialogue forming additional lexical material is needed, in its turn, it can be obtained by reading, listening or watching films in a foreign language. Undeniably, there is a need for control or self-control of language performance, which can be done by recording new lexical units or constructions, and then by using them during the dialogues development.

Language orientation is a logical conclusion from the subject of study. Here we understand the psychological resource that affects the overall process of thinking, the product of which can be identified as speech acts, oral or written. That is, selected methods should direct the transfer of information from the level of comprehension to production, and a process of thinking in a foreign language will be a result. Y. Passov describes this process as a transfer of acquired habit (operational level) to speech skills (motivation and thinking level), and indicates the existence of sublevels of this transition, provided by the dosing of language material [3, p. 32]. During the selection of means and methods of teaching the educator must take into account the true need to repeat and work out the pre-acquired information, lexical units and structures. That is, in order to achieve the transition, it is necessary to take exercises that targeted not to provide technical repetition-speaking actions, but those having a certain speech aim to understand and solve the problem, and implement a certain speech act (oral or written).

Gnostic, cognitive orientation of the organization of the process of studying a foreign language is a subject to master the general cultural, general technical elements associated with the language of study. Cognitive orientation in combination with the principle of novelty in learning is an additional means of motivation.

It should be noted that a communicative approach to learning should cover all levels, such as verbal, grammatical and cognitive. That is, in order to communicate it is necessary to expand not only the linguistic picture of the world, but also extra-language one, which is based on peculiar associative and sensory images related to the subject of speaking. Students must not only learn lexemes, but also feel the atmosphere of the environment in which the language of study is formed. We consider it expedient to use authentic video and audio materials here. N. Skidanova notes that involvement of authentic materials in groups takes place in three stages: preparatory, textual and demonstrative. Although the author considers a preparatory stage as an acquaintance with vocabulary and an attempt to find out the meaning of the name in accordance and through further discussion, the additional tasks may be engaged such as problem-solving ones, specially selected by the teacher. It provides students' mental activity during viewing (listening). Polish researcher V. Bronyarka suggested an author's method of working with the text, which is to read the text aloud in a foreign language and analyze it with the means of translation into the language of communication (depending on the level of the group it can be verbal or literary translation), and then again transfer it into foreign language using a newly translated text $[6$, p. 59]. Through this approach students can not only obtain new vocabulary units, but also practice grammar, besides, mentioned sort of learning activity is connected with the creative thinking and development of language intellectual capacities.

Involving different texts in the process of learning is not only optional, but also necessary, since the mechanical learning of words, phrases and phraseological units does not give long-term results, in particular, it produces a temporary skill that is not transmitted into ability. Working with the text contributes to a deeper immersion in the world of language and speech, because words are presented in the context, that is, by reading and translating students recognize, semantisize and memorize the meaning of a particular word. This helps avoid a situation when a number of non-related translation-equivalents in the dictionary do not respond to a specific communicative situation. The Internet offers a number of translated dictionaries, among which the Reverso Context platform has gained its popularity, which offers not only vocabulary interpretation in accordance with the part-language affiliation, but also provides modern contexts where the word reveals its meaning. The additional benefit of this program is the ability to listen to pronunciation of words or sentences by the native speaker. The disadvantage may be the limited set of languages offered by the program: Arabic, German, Spanish, French, Hebrew, Italian, Japanese, Dutch, Polish, Portuguese, Romanian, Russian. Thus, the use of the following software is entirely successful for mastering the available languages, because it covers the language completely due to the trinity of speaking backgrounds: vocabulary, grammar, phonetics.

The personality orientation of teaching a foreign language is manifested at the moment of the formation of personality traits in the process of educational activity and is indisputable, since each person is a unique bearer of experience both linguistic and practical, which contributed to the development of an individual picture of the world, which at the subconscious level rejects superfluous information, it contradicts the previously received installations, and leaves the one that complements the existing ones. The process of development students' experience is mainly due to their professional activities, which contributes to the expansion of the world of a specialist. Different exercises and tasks should be related to the students' previous experience, but for effective influence on the individuality it is worth turning to creative tasks. Given the interest to students and the effectiveness of language learning, we can distinguish the design method, the method of "brain attack", "the case study" approach, and the method of business role-playing games. They facilitate the individual selection of information that is related to professional activity and does not contradict own judgments, and the implementation of tasks is carried out in several stages, such as the reception and comprehension 
of the task; working on tasks; problem solving; presentation of the result. That is, the reception of new material is motivated, meaningful and repetitive, it passes the path from the operational to the motivational and mind level.

Regulatory and willing orientation takes the leading place, since often the number of classroom hours is limited, and the volume of material for learning is significant, therefore, it is extremely important for the teacher to develop students` regulatory mechanisms of the mind during classes, including the use of suggestopedic technologies.

It is impossible to limit the language learning exclusively to classes, so the need to repeat and summarize the information obtained during the classroom hours should be carried out by the student and independently, so the teacher's task is to organize the educational process in a way to encourage students to obtain and expand their lingual competences on his own, moreover, to motivate their desire to self-training. Here the innovative technologies of studying foreign languages come to the aid.

$\mathrm{N}$. Lagutina calls the use of modern technological means an intensifier of teaching a foreign language. We agree that the role of computer software greatly simplifies the process of providing independent work and it can be tested at all levels of speech activity. Thus, electronic textbooks provide an opportunity to present illustrative and actual material more widely, in addition, they can make changes in accordance with the specialty and urgent needs. The user-friendly interface helps you easily find the right information, saves you time. Of course, not any educational institutions can develop or buy the most innovative software for learning a foreign language, and for language teachers such a task may be overwhelming as well, so a number of existing and functioning programs well-known in a community of the Internet users come to the aid. A very functional one to develop the ability to correctly pronounce and expand the vocabulary has become the online platform FORVO, which allows you to listen to the pronunciation of a native speaker. Everyone can join the development of this site and spell a few words, indicating the area where they live.

Like the previous resources taken when learning a foreign language, the creative focus has already been mentioned. Here we are talking not about students` linguistic and creative activity, because at the level of development of communicative skills a process of attracting and transferring to the thinking level of new lexical units, constructions and grammatical categories occurs, but the use and formation of creative qualities in the process of using innovative technologies of learning.

The creative focus of learning is directly related to personal orientation and self-education. Often, teachers offer students experience of engagement into mutual creative activity by preparing reports, presentations to topics, books, and films for further discussion in the class. The improved symbiosis of these techniques is Case Study, which in Ukrainian pedagogical literature is called a casemethod, "a case". At the beginning of the twentieth century this method was used at the Harvard Business School, and later began to be used when studying other humanitarian disciplines. It implies providing a group of students with a peculiar "case" with specially prepared problemspecific samples, situations, stories, texts, which need to be jointly analyzed, discussed in order to make a decision [5]. The versatility of this method is complex, since the implementation of the proposed tasks of the case involves the development of a specific situation associated with the involvement of related knowledge, independent work, "brainstorming", a public statement in which participants defend their own decision, a final oral test on the facts of developed "case". An important factor for this method implementation is a group work that implies the principle of interactivity, that is, students have the opportunity to create a common fund of information on the subject to use it by all members of the group, that is, everyone's motivation increases, which facilitates the successful assimilation of information.

The active orientation of the educational process of learning a foreign language is an urgent need, since the actual communicative activity is both the goal of the study itself and the means. Learning the language as passive contemplation or listening to the material is impossible, since the communicative method involves the need for the ability not only to perceive the given information, but also to express, that is, any chosen method, or technique, or the means of training has an activity orientation.

Motivational orientation is one of the preconditions for the successful assimilation of communicative skills. Y. Passov relates motivation with two kinds of needs:

1) a need for communication, inherent in any human as a member of society;

2) a need to implement a specific speech act, need to intervene in a specific speech situation.

If the first need is general, then the second one, in accordance with researchers' view, contributes to the formation of persistent interests that provide the student with true intentions for communication in general, forming a permanent motivation readiness, that, in its turn, is an important factor in the successful study of a foreign language [3]. Moreover, the task of a teacher in the classroom is not only to submit the material, but also to interest, create a need for students to speak, to prove their opinion, to expand the participants`culture and language world views.

Conclusion. The process of foreign language acquisition is based on a number of psychological and methodological resources referred to its communicative nature, that need to be constantly used for the successful development of spoken skills. The teacher should take into account socializational, linguistic, cognitive, personallyoriented, regulatory, creative, and motivational directions of foreign language education. Current investigation briefly outlines the implementation options for the teaching with the use of these resources, clarifies the essence of them and proposes appropriate methods with a specific commentary in order to outline important aspects and complexities in their application and implementation. The proven importance of the aforementioned factors for successful foreign language learning requires a broader analysis and experimental confirmation that is promising for further research. 


\section{ЛИТЕРАТУРА}

1. Азимов Э. Г., Щукин А. Н. Новый словарь методических терминов и понятий (теория и практика обучения языкам) / Э. Г. Азимов, А. Н. Щукин. - М. : ИКАР, 2009. $-448 \mathrm{c}$.

2. Білан Н. Комунікативний метод навчання іноземних мов студентів немовних ВНЗ / Н. Білан // Молодь і ринок. Дрогобич, 2012. - 5(88). - С. $149-153$.

3. Пассов Е. И. Коммуникативный метод обучения иноязычному говорению / Е. И. Пассов. - M. : Просвещение, 1991. -223 c.

4. Цимбал С. В. Психологічні особливості формування професійної компетентності спеціалістів засобами іноземної мови : автореф. дис. на здобуття наук. ступеня кандидата психолог. наук за спец. 19.00.07 «Педагогічна та вікова психологія» / С.В.Цимбал ; НАДПСУ імені Богдана Хмельницького. - Хмельницький, 2006. - 28 с.

5. Ягоднікова В. В. Кейс-метод (Case study) як форма інтерактивного навчання майбутніх фахівців / Ягоднікова В. В. // Секція «Педагогічні науки», підсекція № 5. [Електронний ресурс]. - Режим доступу : http://www.rusnauka.com/1_NIO_2008/Pedagogica/25496.do c.htm.

6. Zagoruiko L., Kapeliushna T. Polish experience of usage innovative methods of teaching foreign languages // Порівняльно-педагогічні студії. - Умань, 2017. - 1(31). - С. 58 62.

\section{REFERENCES}

1. Azimov E. G., Shchukin A. N. New dictionary of methodical terms and notions (theory and practice of teaching languages) / E. G. Azimov, A. N. Shchukin. - M. : ICAR, 2009. - 448 p.

2. Bilan N. The communicative method of teaching foreign languages to non-native high school students / N. Bilan // Youth and Market. - Drohobych, 2012. - 5 (88). - P. 149 - 153.

3. Passov Y.I. Communicative method of teaching foreign speaking / E. I. Passov. - M. : Enlightenment, 1991. - 223 pp.

4. Tsymbal S. V. Psychological peculiarities of professional competence development for specialists with the means of foreign language : thesis for obtaining a Scientific Degree of the Candidate of Psychological Sciences in specialty 19.00.07
«Pedagogical and Age Psychology» / S. V. Tsymbal ; NADPSU named after Bogdan Khmelnytsky. - Khmelnitsky, 2006. $-28 \mathrm{p}$.

5. Yagodnikova V.V. Case study (case study) as a form of interactive training of future specialists / Yagodnikova V. V. // Section «Pedagogical sciences», subsection No. 5. - [Electronic resource]. http://www.rusnauka.com/1_NIO_2008/Pedagogica/25496.do c.htm.

6. Zagoruiko L., Kapeliushna T. Polish experience of using innovative methods of teaching foreign languages // Comparative-pedagogical studios. Uman, 2017. - 1 (31). - P. 58 - 62.

Использование психолого-педагогических ресурсов в процессе изучения иностранного языка: коммуникативный ракурс

Т. Н. Агибалова, Е. В. Алпатова

Аннотация. В статье рассматриваются ресурсы и методы изучения иностранного языка с психологической, педагогической и коммуникативной точки зрения. Психолого-педагогический ракурс коммуникативного подхода выходит на первый план и является центральным принципом обучения иностранному языку, поскольку он охватывает ряд важнейших для успешного усвоения материала факторов. Представленные в статье психолого-педагогические ресурсы проанализированы с точки зрения важности и проиллюстрированы методами и способами их реализации в учебном процессе.

Ключевые слова: языковая компетенция, языковая картина мира, психологический ресурс, метод обучения, мотивация. 